\section{The alienating language of health care}

Language is one of the many tools of medicine. Language can educate and inform or confuse and mislead. Language can inspire or alienate, cherish or insult. It is increasingly recognized that communication between clinicians and patients is one of the most important aspects of the healthcare relationship and yet the way language is used in the health service is often opaque, alienating and disrespectful.

My attention was drawn to this recently by the emergence in the media and in management speak of the term 'frequent flyers' to describe those frail, mainly older people who come in and out of hospital on a regular basis. The term 'frequent flyer' in this context is demeaning, trivializing and of course plain wrong. It implies that somehow these people want regular trips to hospital, that they are collecting points, that they enjoy the health and life threatening roundabout of continual admission, treatment and discharge.

The health service uses language in this way to shift the blame. By using 'frequent flyer' we imply that patients are acting out of choice whereas of course people who are forced to attend hospital too frequently are a sign of our failure. 'Bed blockers' is another alienating term which shifts the blame from the NHS to the patient as, in its different way, is the reduction of all of us who don't turn up for appointments to 'DNAs'.

Categorizing people as DNAs allows the service to avoid looking at why its appointment system doesn't work. I confess to being a DNA. I became one because the appointment letter was sent to the wrong address. I didn't even know I was expecting an appointment letter. What is it about the NHS and appointments? It is the only organization I know where the word 'appointment' means an instruction to attend rather than an agreement between two parties to meet. And why does the NHS feel the need to SHOUT at me? Appointment letters are constructed unlike any other with strange uses of typefaces, capital letters and italics. 'Dear MR CAYTON', they bellow. 'Your APPOINTMENT is on Monday 17th July . . .' they go on. Nor should you imagine that the appointment time is real. A colleague of mine, taking his elderly mother who has Parkinson's disease from her care home to see a consultant, was told to arrive at $9 \mathrm{am}$. This of course meant getting a frail, unsteady lady out of bed and dressed at seven in the morning. When they got to the clinic the consultant hadn't even arrived and didn't do so until well after the first appointment time was passed. No explanation or apology was given. It's not surprising some of us become DNAs.

Labelling people in this way is the most common way in which the NHS dehumanizes those it is supposed to care for. As well as notorious terms such as 'crinklies' and 'crumblies' sometimes used in geriatric wards, people are also reduced to no more than their condition; 'We have two hips and a knee in today' in the surgical ward or the diminution of a human being with Alzheimer's disease to no more than a 'Dement'.

It is interesting to note that this language is most commonly used about older people. Older people generally use the health service most often but they are also sometimes the least able to speak up for themselves, the most vulnerable. Maybe the embedded ageism in society allows these terms to be more acceptable.

So what might be done about this use of alienating and dehumanizing language and does it even matter? Is my disgust just another example of political-correctness-gonemad? I can understand in the stressful environment of health care, when you are working close to pain and disease and possibly death, you need some distance. This language establishes distance by turning people into objects. But there are other, kinder ways of achieving detachment and, yes, language does matter. Language both reflects and shapes our thinking and thus our behaviour. Discourtesy cannot be the basis on which a healing relationship is built. The reduction in sexist and racist language has not eliminated sexism and racism but it sets a context and an environment in which sexism and racism are more shocking and tolerated less. We must do the same with the language of blame and disrespect. We are a long, long way from patient-centred health care and our language betrays us.

\section{Harry Cayton}

National Director for Patients \& the Public, Department of Health, Whitehall, London SW1A 2NS, UK

E-mail: Harry.Cayton@dh.gsi.gov.uk 